\author{
А. А. ГРЕЧКО ${ }^{1}$, Ю. В. МІРОШНИК ${ }^{1}$ \\ ${ }^{1}$ Харківський національний університет імені В. Н. Каразіна \\ майдан Свободи, 6, м. Харків, 61022, Україна \\ E-mail: alinkaandreevna23@gmail.com \\ miroshnik1993@gmail.com
}

\begin{abstract}
ПРО ПРОВЕДЕННЯ І МІЖНАРОДНОЇ ІНТЕРНЕТ - КОНФЕРЕНЦІЇ «АКТУАЛЬНІ ПРОБЛЕМИ ФОРМАЛЬНОЇ І НЕФОРМАЛЬНОЇ ОСВІТИ 3 МОНІТОРИНГУ ДОВКІЛЛЯ ТА ЗАПОВІДНОЇ СПРАВИ»
\end{abstract}

\author{
A. A. HRECHKO ${ }^{1}$, Y. V. MIROSHNIK ${ }^{1}$ \\ V. N. Karazin Kharkiv National University, \\ 6, Svobody Square, Kharkiv, 61022, Ukraine \\ E-mail: alinkaandreevna23@gmail.com \\ miroshnik1993@gmail.com
}

\title{
ON THE CONDUCT OF I INTERNATIONAL INTERNET CONFERENCE «CURRENT ISSUES OF FORMAL AND NONFORMAL EDUCATION IN ENVIRONMENTAL MONITORING AND CONSERVATION»
}

Наприкінці лютого 2021 року кафедрою екологічного моніторингу і заповідної справи Каразінського ННІ екології вперше проведено Міжнародну інтернет-конференцію «Актуальні проблеми формальної і неформальної освіти з моніторингу довкілля та заповідної справи». Тематикою конференції обрано шість ключових питань, які стосуються сучасних проблем формальної і не формальної освіти у галузі заповідної справи, а саме:

1. Актуальні напрямки формальної та неформальної освіти у заповідній справі;

2. Розвиток зеленого туризму на території об’єктів ПЗФ;

3. Міжнародна наукова та освітня діяльність в галузі заповідної справи;

4. Освітні інновації у моніторингу стану навколишнього середовища;

5. Моніторинг довкілля : сучасний стан, перспективи та міжнародний досвід.

6. Methodological Aspects of Teaching English in the Educational program «Protected Areas».

Окремою активністю конференції стало проведення круглого столу Досвід запровадження спільної докторської програми за проектом ERASMUS+ «INTENSE: Integrated Doctoral Program for Environmental Policy, Management and Technology».

До організаційного комітету надійшло 40 тез від різних авторів та колективів авторів. У день конференції зареєструвалось 60 учасників. До участі в обговоренні проблематики конференції залучились представники різних міст України, серед них: Харків, Київ, Полтава, Львів, Суми, Житомир, Миколаїв, Новий Буг, Надвірна, смт Дворічна та інших. У конференції взяли участь різні освітні установи:

- Київський національний університет імені Тараса Шевченка.

- Львівський національний університет імені Івана Франка,

- Львівський національний аграрний університет,

- Національний університет "Львівська політехніка",

- Національний університет «Полтавська політехніка імені Юрія Кондратюка», Державний університет «Житомирська політехніка»,

(C) Гречко А. А., Мірошник Ю. В., 2020

(c) $\mathbf{E Y}$ This is an open access article distributed under the terms of the Creative Commons Attribution License 4.0. 
- Луцький національний технічний університет, кафедра екології та агрономії,

- ВСП "Педагогічний фаховий коледж" ЛНУ ім. І. Франка,

- Харківський національний економічний університет імені С. Кузнеця,

- Сумський національний аграрний університет

- Національна академія сухопутних військ імені гетьмана Петра Сагайдачного

- Національний університет біоресурсів і природокористування України

- Чорноморський національний університет ім. Петра Могили

- RBGE, Scotland, UK

- Edinburgh University, Scotland, UK

- Харківський національний університет імені В. Н. Каразіна,

До обговорення також залучились представники природоохоронних установ 3 різних куточків України: Дунайського біосферного заповіднику, Чорноморського біосферного заповіднику НАН України, Природного заповіднику «Горгани», Природного заповіднику «Михайлівська цілина», Регіонального ландшафтного парку «Приінгульський», НПП «Дворічанський», НПП «Мезинський», НПП «Пирятинський», НПП «Слобожанський», НПП «Черемоський», НПП «Кармелюкове Поділля», НПП «Яворівський», НПП «Олешківські піски» (рис. 1).

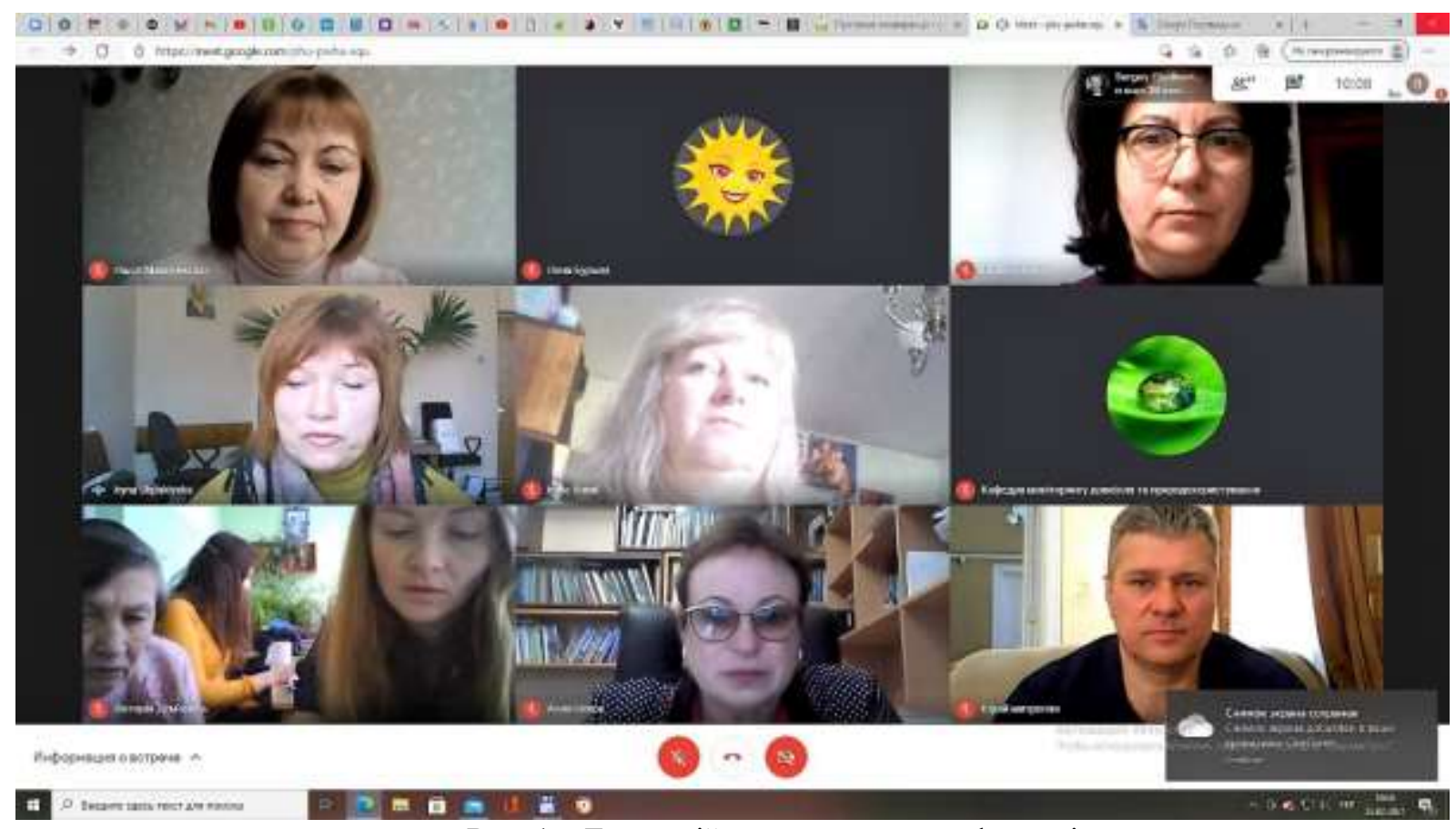

Рис. 1 - Дистанційне проведення конференції

Учасники конференції під час виступів ділились власним досвідом в сфері викладання та застосування сучасних методів для поширення інформації природоохоронної тематики у навчальних закладах та на території об'єктів ПЗФ, залучення студентів закладів вищої освіти та школярів до наукової діяльності в межах природоохоронних територій, про проведення практик студентів у межах заповідних територій.

Також важливим аспектом обговорення стала тема неформальної освіти, адже вона забезпечує поширення інформації щодо цінності природних об'єктів, ознайомлення із рідкісними, зникаючими та іншими видами як флори так і фауни, розповсюдження знань 3 приводу важливості збереження таких об'єктів. Враховуючі різноманітність форм представлення неформальної освіти, саме вона дозволить поширювати інформацію серед різновікових груп населення, формуючи екологічно свідоме ставлення до навколишнього середовища.

Дуже приємно, що у конференції брали участь не лише представники природоохоронних установ, навчальних закладів академічних інститутів (ННЦ «Інститут грунтознавства і агрохімії iм. О. Н. Соколовського», Українського науково-дослідного інституту лісового господарства i 
агролісомеліорації ім. Г. Н. Висоцького», Інститут екології Карпат НАН України), але й представники управлінських структур. Активну участь в обговоренні проблем заповідної справи в Україні взяв член Робочої групи з питань заповідної справи Комітету екологічної політики та природних ресурсів Верховної Ради України Гладкевич Сергій. - незалежний експерт дикої природи, журналіст, член Робочої групи з питань заповідної справи.

Органи виконавчої влади представляли Департаменти екології та природних ресурсів Харківської і Львівської ОДА, а також Управління екології та природних ресурсів Миколаївської облдержадміністрації.

Запропоновано нові цікаві ідеї для розбудови заповідної справи в Україні. Всі учасники прийшли до висновку, що лише постійна плідна співпраця може привести до нових досягнень у заповідній справі.

Окремим напрямком роботи конференції стало обговорення проблем підготовки висококваліфікованих кадрів для природоохоронних установ. Зазначено, що низька підтримка держави в розбудові екологічної мережі проявляється у відмові від виділення бюджетних місць для прийому абітурієнтів у бакалаврат і магістратуру на освітню програму «Заповідна справа». 3 цією проблемою сикається Каразінський університет, який з ліцензійного обсягу спеціальності 101 Екологія два роки поспіль виділяє по 5 місць на денному бакалавраті для ОП «Заповідна справа», а держава на першому році надала 2 бюджетні місця, а на другому році взагалі відмовила у бюджетних місцях і лише велике бажання студента спонукало його до вступу на навчання за власний кошт. Аналогічна ситуація з магістерською програмою.

Окрім дискусій на важливі теми, які було представлено в ході проведення конференції, також обговорено приємні спогади від любительських подорожей учасників заходу і обмін враженнями від відвідування природоохоронних територій.

Дана конференція проведена на високому організаційному рівні. Сподіваємось, що рекомендації, які надано під час жвавих дискусій, матимуть практичне значення для реалізації програм та проектів у сфері заповідної справи. Всі учасники конференції отримали на згадку про цю подію сертифікати учасників, а також електронну версію збірки конференції (рис. 2).
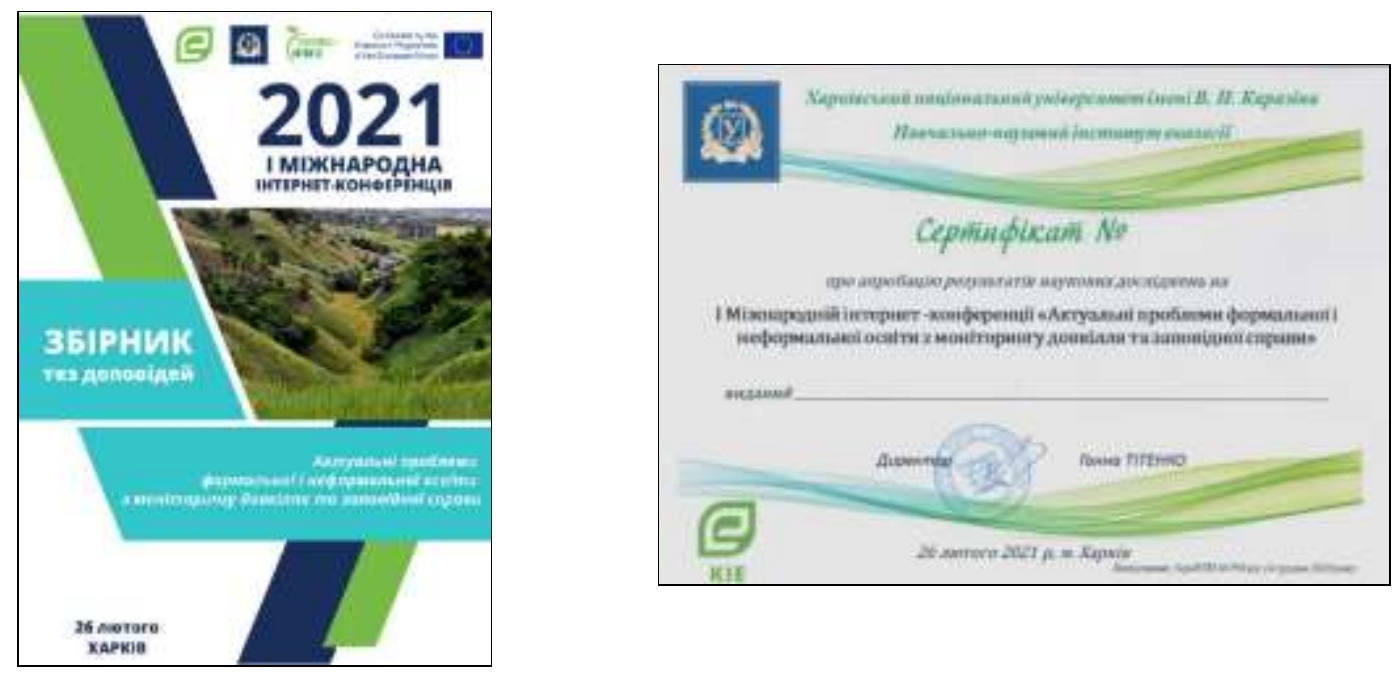

Рис. 2 - Збірник матеріалів конференції та сертифікат учасника

Планується цю конференцію зробити щорічною і перетворити на популярний майданчик для обговорення актуальних проблем заповідної справи. Детальну інформацію про конференцію та збірник тез можна знайти на сайті НHI екології http://ecology.karazin.ua/vidannja/ та кафедри екологічного моніторингу та заповідної справи http://ecomonitoring.karazin.ua/ .

На конференції презентувались матеріали грантових проектів від:

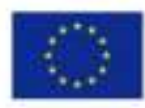

